\title{
History of Behavioral Neurology
}

Sergio Daniel Barberis ${ }^{a}$ and Cory Wright ${ }^{b},{ }^{a}$ Department of Philosophy, Faculty of Philosophy and Literature, University of Buenos Aires, Buenos Aires, Argentina; and ${ }^{b}$ Department of Philosophy, California State University Long Beach, Long Beach, CA, United States

(C) 2020 Elsevier Ltd. All rights reserved.

$\begin{array}{lr}\text { Behavioral Neurology as a Branch of Medicine } & 1 \\ \text { Ancient } & 1 \\ \text { Classical } & 2 \\ \text { Medieval } & 3 \\ \text { Renaissance to Enlightenment } & 4 \\ \text { Modern } & 5 \\ \text { Contemporary } & 9 \\ \text { Back to the Future } & 12 \\ \text { References } & 12\end{array}$

\section{Behavioral Neurology as a Branch of Medicine}

Behavioral neurology is primarily concerned with the neurological causes of degraded behavior following disruption of higher brain function. In the early 1970s, it re-emerged as a subspecialty of neurology focused on diagnosing and treating patients with damages, diseases, and disorders of the nervous system and related tissues that alter normal behavior. While some practitioners have studied congenital diseases and geriatric dementias, behavioral neurology came to overlap extensively with the fields of neuropsychiatry and neuropsychology, differing primarily in the degree of medical diagnosis and treatment of patients. The major advances in neuropsychology and neuropsychiatry are thus part of the history of behavioral neurology.

Contemporary behavioral neurology has developed foci in common with the neurosciences, but both have evolved noteworthy differences in remit, scope, and clinical emphasis. As a branch of medicine, the former normally requires expertise in the management of the molecular and neurochemical basis of behavioral disorder, the ability to relate functional and structural conditions to clinical data using imaging techniques and electrophysiological methods, the implementation and interpretation of neuropsychological and neuropsychiatric assessments, and comprehensive clinical diagnosis and therapeutic treatment. By contrast, as a branch of science, the latter has crystalized into an academic discipline concerned with epistemological successes about the neural bases of behavior (basic research) and the use of that knowledge in new technologies and developments (applied research). Medicine is a far older profession than science; by implication, behavioral neurology, as a branch of medicine, is a far older field than neuroscience.

This history of behavioral neurology divides into six eras: ancient, classical, medieval, post-Renaissance, modern, and contemporary. In some cases, the divisions correspond neatly to major intellectual boundaries, such as the division between ancient and classical periods by Galenism and between modern and contemporary periods by Geschwind's (1965) two-part opus. In others, the boundaries are such that no non-arbitrary division can be established.

\section{Ancient}

Among the oldest surviving scholarly works in neurosurgery is the so-called 'Edwin Smith Surgical Papyrus' (Breasted, 1930). Now dated to around ${ }^{\text {bce }} 1600$, the papyrus is an amalgam of 48 case descriptions transcribed from a much older treatise that are sometimes conjectured to derive from the time of Imhotep (floruit bce 2645 ). The first 33 cases describe neck and head injuries; they relate trauma and gross anatomical damage to deficits-including hemiplegia, loss of speech, and seizures-and prescribe various treatments or palliative measures. The papyrus contains a hieretic lexeme for the term brain, one of humanity's earliest recorded uses. Similar Babylonean surgical texts offer descriptive taxonomies of symptoms now associated with seizures, headaches, meningitis, narcolepsy, cranial nerve injuries, and sundry other conditions, and associate with them various prognostications ranging from recovery to imminent death (Scurlock \& Andersen, 2005). These taxa are invariably bound up with fantastic mythologies; but together with surviving texts from Chaldean, Mycenaean, Chinese, Mayan, etc. civilizations, they show that ancient physicians were familiar with the behavioral consequences of brain damage.

During the archaic period, Magna Graecia was a main locus of innovation. Alcmaeon of Croton (floruit ${ }^{\text {bce }} \sim 490$ ) was an early medical philosopher contemporaneous with the Pythagoreans on the Bruttian peninsula. Although postmortem surgery was rarely performed and culturally proscribed, Alcmaeon excised the eye and possibly the optic nerves (Lloyd, 1975), and arguably was the first to connect perceptual considerations to the construal of the brain as an organ of the sensorium and intellect. From his empirical studies, Alcmaeon inferred that sensory organs are connected to the brain, and the brain to muscles, by channels (poroi) and cords (neura, tonoi), and was an early proponent of the thesis that they transport various 'spirits' (naturalis, zooticon, and psychikon). The pre- 
Socratic Miletians—-particularly the Anaximenean disciples, such as Diogenes of Apollonia (floruit ${ }^{\text {bce }} \sim 435$ ) - developed this thesis by regimenting descriptions of anterior vascular anatomy, which included considerations of ischemic neuropathy, and postulating the movement of pneuma and its admixture with blood within the brain (hence the etymological connection between the Greek term for air, $\alpha \dot{\varepsilon} \rho \alpha \varsigma$, and the Latin arteria).

The near-eastern Mediterranean from Cos to Alexandria was another major locus of ancient neurological study. Hippocrates (bce 460-375) and the other Asclepiads of Cos and Cnidus summarized then-current medical knowledge into what would become the Corpus Hippocraticum (Littré, 1973), a compendium of $>60$ works by different writers. Hippocrates himself was likely an early advocate of humoralism, which posited four states-sanguine, choleric, phlegmatic, and melancholic - thought to constitute the biophysical basis of personality. Although not gripping, humoralism was importantly false: it anticipated the 19th century concept of homeostasis, and issued naturalistic explanations of psychological temperament by appealing to biological disorders (dyskrasias).

Neurology in the ancient period was typically merely responsive: common foci were the treatment of headaches and seizures, combat wounds, and palliative responses to effects of surgical interventions. However, these developments across the Mediterranean basin commenced an important tradition of pre-Hellenistic physical philosophers (physiologi) investigating the brain and body, beginning with the dissections by the three directors of the Athenian Lyceum: Aristotle ( $\left.{ }^{\text {bce }} 384-322\right)$, Theophrastus ( ${ }^{\text {bce }}$ 370-287), and Strato of Lampsacus ('bce 335-269).

In Alexandria to the south, Herophilus of Chalcedon ( ${ }^{\text {bce }}$ 330-260) also performed hundreds of dissections, probably of dubious legality, establishing the distinctions between cerebrum (enkephalos) and hindbrain (parenkephalis) and between meningeal layers, and leading to intense curiosity about ventricular function. Erasistratus ( ${ }^{\text {bce }} \sim 304-250$ ), to whom Celsus ( ${ }^{\text {bce }} 26-50{ }^{\text {ce }}$ ) ascribed human vivisections, further distinguished between neurons and tendons, traced the path of afferent nerves from the hindbrain, and, according to Rufus of Ephesus $\left(\sim 70-150^{c e}\right)$, hypothesized different functions of sensory and motor nerves (Solmsen, 1961). Erasistratus also anticipated Harvey's discovery of circulation. More notable, though, was his decisive pivot toward empirical methods, which would eventually result in construing the brain as the governing organ (hêgemonikon), albeit with pneuma as its central physiological agent.

\section{Classical}

Herophilus and Erasistratus were intrepid anatomists, and their replacement of cardiocentrism with encephalocentrism make them the most important figures in ancient neurology. Thereafter, neuroanatomy fell quiescent for three centuries, with empirical discovery ceding to scholarly commentary during the Ptolemaic dynasty.

The transition from the Roman Republic to the Roman Empire, following Octavian's defeat of Marcus Antonius and Cleopatra VII, created the stabilizing conditions under which traditions of anatomical research could eventually be recovered. Marinus of Alexandria (70-120 ${ }^{\mathrm{ce}}$ ) helped usher neurology into the classical period (Rocca, 2003). In attempting to relate paralytic symptoms to contralateral damage, Aretaeus of Cappadocia (floruit $140^{\mathrm{ce}}$ ) noticed the decussation of motor nerves. However, close study of the behavioral effects of neuropathology had to wait upon more systemic empirical explorations.

That jump occurred with Galenus of Pergamon $\left(129-216^{\mathrm{ce}}\right)$, who was by far the most important and influential figure in neurology during the classical period. Like Marinus and his teachers, Galenus performed dissections of cranial nerves, introducing functional distinctions between auditory, facial, oculomotor, optic, trigeminal, and vagus nerves; and he made clinical observations that allowed him to correlate spinal injuries and their behavioral consequences (see Fig. 1). Like Hippocrates, he played a scholarly role by synthesizing centuries of scholarship to distinguish between complex structures of the brain from merely spatial parts, including the dura and pia mater, corpus callosum, fornix, and pineal and pituitary glands; but he also broke with some of that

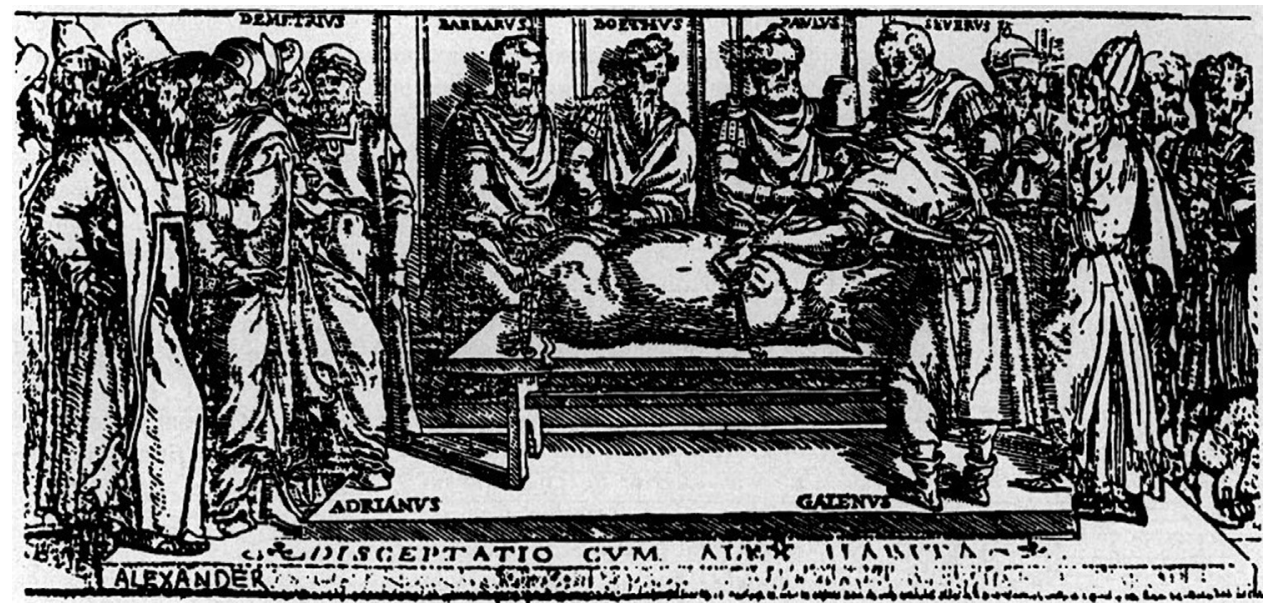

Figure 1 Galenic pig vivisection. 
scholarship. He conjectured that the softness of sensory nerves, being more easily alterable, is what provides for the receipt of sensory information, and he localized the sensorium to the cerebrum because of its relative softness, analogously; being harder, Galenus reasoned that the cerebellum is primary in the control of movement. While Galenus's humoralism is notorious, it was his engagement of the pneumatological views of the Athenians and Alexandrians that had lasting influence. Galenus was renown for demonstrations-including competitive 'duels' or 'truth-contests' with other vivisectionists-of his anatomical and physiological knowledge (Gleason, 2009). In one with Martialius (150-190 ${ }^{\mathrm{ce}}$ ), a cantankerous old-fashioned cardiocentrist, Galenus reportedly ligated an aorta to falsify the thesis that arteries convey pneuma, and then applied pressure to the ventricles ad seriatim to demonstrate stupor, progressive paralysis, and apoplexy.

Ventricular or 'cell' theory at that time postulated three cells, which were thought to allow jointly for the transformation of inhaled air, admixed with cerebral fluids and vital pneuma from the heart, into animal spirit. Each cell served as a register for a different mental function. The anterior-most ventricle received what were thought to be pneumatic presentations of objects from the sensorium, with pneuma being compressed into the middle ventricle to be operated on by reason and imagination, with some of those presentations being deposited as memories into the posterior ventricle. The brain's collapse following cerebrospinal fluid loss from ventricular dissection, as recorded between $169-175^{\text {ce }}$ in Galenus's De Anatomicis Administrationibus (/1956) and De Usu Partium (/1968), gives the impression of the kind of 'structural deflating' that would have made pneumatic ventricular theory compelling.

\section{Medieval}

The Hellenistic history of behavioral neurology was a quiet subperiod in which the research of Herophilus and Erasistratus happened not to get lost. The classical period ended by repeating that pattern. With the rise of Christendom from Tertullian $\left(155-240^{\text {ce }}\right)$ to Constantine $\left(272-337^{\text {ce }}\right)$, neurology went dormant; while scholars like Oribasius $\left(325-403^{\mathrm{ce}}\right)$ organized medical knowledge into compendia, the hard-won conditions for original discovery slipped away. This was especially so once Athens and Alexandria-despite remaining major loci of medical study-were eclipsed during the transition between the Roman and Byzantine empires.

Pagan commentators passed Galenic views to the Christian clergy via medical scribes, albeit in atmospheres increasingly inhospitable to scientifically-oriented philosophy. Humoralism, for example, was increasingly attacked by theologians like Philostorgias (368-439 $\left.{ }^{\mathrm{ce}}\right)$, as it implied that the ill are beset, not by supernatural malagents (daimones), but by unhealthy combinations of natural humors. Unsurprisingly, medieval neurology is frequently disparaged: 'the advances in understanding the brain in medieval Europe are easy to summarize: there were none' (Gross, 1987: 845). However, as Schalick notes, that assessment is too quick: '[medieval neurology] has been described as intellectually stagnant and practically chaotic [...] Neither the stagnant nor the chaotic attribute is accurate' (2009: 79). In these circumstances, the passage of Galenic views about ventricular localization persisted, in part because they were underspecified, and thus easily amended and protected from falsification. Posidonius of Byzantium (floruit $\sim 380{ }^{c e}$ ) and Nemesius of Emesa (floruit $\sim 390^{\mathrm{ce}}$ ), for instance, maintained the commemorative account of the posterior ventricle, but parsed the functions of the middle ventricle - the ratiocinative and the imaginative - into the middle and anterior, respectively. Galenic views were also kept in play by attempted refutations of rival Aristotelian and Neoplatonist views, such as those of John Philoponus (490$570^{\mathrm{ce}}$ ), and by various medical compilers and translators like Sergius of Resh'aina (floruit $\sim 520^{\mathrm{ce}}$ ), Paulus Aegineta (625-690 ${ }^{\mathrm{ce}}$ ), and Johannitius (809-873 $\left.{ }^{\mathrm{ce}}\right)$.

Neurology was reinvigorated during the Persian Golden Age. Indeed, there are too many figures and developments to recount here. Notable is Rhazes (865-925 ${ }^{\mathrm{ce}}$ ), who advocated experimental methods and pharmacological treatments, and whose Kitab-alHawi described various neurological disorders, including hemiplegia, facial palsy, asthenia, and various peripheral nerve injuries. Joveini (floruit $\sim 960^{\mathrm{ce}}$ ) provided detailed clinical descriptions of psychiatric conditions such as mania, dementia, and psychosis, in addition to asthenia, stroke, epilepsy, and tremors. Abulcasis $\left(936-1013^{\mathrm{ce}}\right)$ and Haly Abbas $\left(949-982^{\mathrm{ce}}\right)$ called forth the GrecoRoman anatomical tradition with their surgical and medical encyclopedias, Kitab al-Tasrif and Kämil al-Sināa al Tibbiya, respectively. Alhazen's (965-1040 ${ }^{\mathrm{ce}}$ ) revolutionary work in optics generated interest in neuroöphthalmology; but it was Avicenna (980-1037 ${ }^{\mathrm{ce}}$ ) that cast the longest shadow into the Renaissance, renewing interest into ventricular localization of the sensus communis and other 'faculties'.

The advent of the university system, starting with Bologna in 1088, provided an important bridge from the Persian Golden Age and began the institutionalization of European centers of scholasticism. After Frederick II's (1194-1250 ${ }^{\mathrm{ce}}$ ) decree authorizing one human dissection every five years at the medical school at Salernum, Bologna added a medical school around 1260 and eventually began enforcing the distinction between vocational barber surgeons and university-trained medical faculty. With increased access to cadavers, Bolognese professors such as Guilielmus de Salicetum (1210-1277 ${ }^{\mathrm{ce}}$ ), who proposed that the involuntary movements originate from the cerebellum, Thaddeus di Alderotto $\left(1223-1303^{\mathrm{ce}}\right)$, and Theodoric Borgognoni $\left(1205-1298^{\mathrm{ce}}\right)$ began teaching generations of students, including Lanfrancus of Milan $\left(1250-1306^{\mathrm{ce}}\right)$ and Mundinus $\left(1270-1326^{\mathrm{ce}}\right)$, who would go on to restore the use of anatomical dissection into the late medieval period. In one case, a leathersmith with intact memory was found postmortem by Borgognoni to have lesions to the fourth ventricle-a cell theoretic anomaly. Lanfrancus innovatively used percussion, string vibration, and other resonance techniques to diagnose skull fractures, and to treat concussions and other traumatic brain injuries. And by 1315, Mundinus was performing university-sanctioned public teaching demonstrations with human cadavers, and composed a dissection manual the following year, Anathomia Corporis Humani (1316/1475). Theoretically, many of these 
scholars remained committed to the frameworks developed by previous Aristotelian and Galenic commentators; methodologically, however, incremental advancements were made. Antonio Benivieni (1443-1502 ${ }^{\mathrm{ce}}$ ) and Niccolò Massa $\left(1485-15699^{\mathrm{ce}}\right)$ pioneered advances in autopsy, forensic pathology, and neurosurgery. In one notable case, a youth struck with a halberd sustained serious head injuries, which comminuted the skull and penetrated the meninges, rendering him speechless. Massa correctly predicted that bone fragments remained lodged in the brain, and partially reversed the loss of speech by extracting them (Benton \& Joynt, 1960).

\section{Renaissance to Enlightenment}

Despite the accumulation of countervailing evidence, the ventricular orthodoxy persisted into the mid-16th century. A consequence of these theoretical commitments was the continued fixation on midbrain structures as the 'seats' of reason, imagination, memory, and other mental faculties. To overcome the difficulty in accessing and then learning about those structures, Leonardo da Vinci (1452-1519) used a casting method to create three-dimensional models: he piped hot wax into the third and fourth ventricles and then peeled away the surrounding basal ganglia to reveal their structure (Pevsner, 2019). While the development of this technique returned no theoretical insights into how damages to the ventricles or disorders in pneumatic admixture might alter normal behavior, it amounted to a crude-but-innovative imaging technique. In his De Naturali Parte Medicinae and Medicina, Fernelius (1497-1558) emphasized the distinction between anatomical structure and physiological function, and brought attention to reflexive behaviors that are not activated by volitional powers of the will. He produced an early description of the spinal canal in Medicina to account for a pathway by which ventricular pneuma could be passed down through peripheral nerves into the muscles and sensory organs.

During the Dutch Golden Age, gross anatomy benefited from promotion of the scientific and cultural values of openness and tolerance, which provided for methodological advances in disclosing bodily structure using innovative instrumentation. Equally crucial were the rapid artistic developments in depictive realism. The works of two scholars are notable, here. First are the groundbreaking reports and illustrations of the Flemish anatomist Vesalius (1514-1564). The culmination of his seven-volume De Humani Corporis Fabrica (1543), which was the first near-comprehensive attempt to map out various systems of the human body, was a book on the dissection of human nervous systems that repayed close study. Vesalius demonstrated that severance or ligature of nerves disrupts their effect on muscle, and his painstaking work helped set up developments in forensic medicine over the next century (an exemplar of which is Théophile Bonet's (1620-1689) nearly 2000-page compilation, Sepulchretum sive Anatomica Practica (1679), which reported on several thousand autopsies performed during the Renaissance). Second is the seminal work of the Dutch physician Pratensis (1486-1558), whose De Cerebri Morbis (1549) discussed various cognitive, mnemonic, and psychiatric conditions, as well as tremors, stupor, and other bodily ailments. While sometimes misdescribed as the first textbook focused on neurology or the first compendium of brain disorders (e.g., Pestronk, 1988), Pratensis's research helped regiment the development of neuroanatomy and pathology.

Both scholars initiated a break from the prevailing Galenism. Vesalius's acknowledgment of morphological similarities between the ventricles of non-/human animals led him to question whether they could be the primary loci of mental function, and whether the ventricles serve purposes other than just being mere cavities for admixing different kinds of pneuma (1543: 623). Other anomalies accrued. The Portuguese physician Lusitanus (1511-1568), for instance, described a case of memory loss following trauma to the occipital boneplate, which led to mesencephalic damage but spared the ventricles. In his Observationes Medica de Capite Humano (1584), Schenckius (1530-1598) collated >500 clinical descriptions of patients with mental and behavioral deficits, including nearly two dozen cases of language disorders. Schenckius also added therapeutic recommendations to his neuropsychological descriptions of speech disruption, and loss of the faculty of reading and writing (litterarum memoria) (Luzzatti \& Whitaker, 1996), and, in some ways, Schenckius's deviation from the ventricular orthodoxy of the time made him a seminal forerunner to the founding of behavioral neurology.

Nonetheless, historical descriptions of the transition from the medieval era often locate the central pivot with René Descartes's (1596-1650) scholarly output (e.g., Feinberg \& Farah, 1997; Koob et al., 2010). Among Descartes's important and lasting contributions is having helped usher in the mechanical philosophy, within which he explored how to account for human behavior in terms of reflex actions by the central nervous system in response to external stimuli. However, these explorations still relied on humoral and pneumatic approaches to Galenic physiology, and so his account of the cerebral seat of sensorimotor coördination fell in line with the conjecture that mechanical repercussions of neuromuscular fluid are transmitted from the sensory organs, and that motor behavior is generally caused by the mechanically gated flow of pneuma from the ventricles, under central mediation by the rational $\psi v \chi \dot{\eta}$ at the pineal gland.

The upper bound on this mechanical philosophy, for Descartes, was the explanatory problem of treating certain aspects of verbal behavior-especially linguistic productivity and communicative flexibility —in mechanistic fashion:

[w] can easily understand a machine's being constituted so that it can utter words, and even emit some responses to action on it of a corporeal kind which brings about a change in its organs [...]. But it never happens that it arranges its speech in various ways, in order to reply appropriately to everything that may be said in its presence, as even the lowest type of man can do. (1637: $§ 5$ ) 
Descartes's posthumously published De Homine (1662) and Traité de l'Homme (1664) did provide a significant framework within which scientists could make progress. But because of this explanatory problem, he simply excepted the rational $\psi v \chi \dot{\eta}$ from mechanistic psychological explanation (see Garber, 2002; Wright \& Bechtel, 2007), which notoriously resulted in a clumsy dualism.

Vivisections by Jan Swammerdam (1637-1680) continued to raise serious doubts about the inheritance of pneumatic ventricular theory. Swammerdam extracted the hearts and brains from an unanaesthetized frogs. Whereas heartless frogs continued to move, brainless frogs did not. Stimulation of laceration-adjacent nerves also caused muscular contraction, demonstrating that movement can occur absent contact between brain and muscle. Swammerdam inferred not only that nervous-not circulatory-tissue is necessary for movement, but that basing behavioral neurology on the transmission of 'animal spirits' (pneuma psychikon) is misguided.

In Oxford to the west, Sedleian Professor of Natural Philosophy Thomas Willis (1621-1675) added a morphological critique of Descartes's 'seat of the soul' account. Pace Descartes, non-human animals - as thoughtless brutes without imaginative or inferential capacities-were expected to have a proportionately smaller pineal gland. Willis's anatomical demonstration to the contrary marked a victory of the empirical over the metaphysical. He and his colleagues developed the first neuroanatomical textbook, Cerebri Anatome, followed by De Anima Brutorum. Willis, who also coined the term neurology, directed Richard Lower's dissections, while speculating with Thomas Millington on neuroanatomical structure and function as Christopher Wren illustrated; in addition to refining descriptions of the cortex and nerves, and making new attributions of differing mechanistic functions to the cerebrum and cerebellum, Willis's team demonstrated the value of collaborative effort. Unfortunately, various religious and political reasons motivated Willis, like Descartes, to exclude the $\psi v \chi \eta \dot{~ f r o m ~ b e i n g ~ c o n s t r u e d ~ a s ~ a ~ m e c h a n i s t i c ~ e x p l a n a n d u m ; ~ a n d ~ W i l l i s ' s ~ o w n ~ a t t e m p t s ~}$ at cerebral localization were subjected to critique.

In his Discours, the undersung neuroanatomist Stenonius (1638-1686) articulated a program for developing neuroanatomical knowledge derived from both scientific principles of verification and falsification and methodological principles of reverse engineering and functional decomposition:

being a machine, we should not hope to find the brain's artifice by other ways than those one uses to find the artifice of other machines. There is therefore nothing left to do besides what would be done to any other machine, I mean to dismantle piece by piece all its components and consider what they can do separately and together. (1669: 32-33)

Stenonius's methodological principles were employed by Marcello Malpighi (1628-1694), a pioneer of early innovations in microscopy and histology, and Raymond Vieussens (1641-1715), who used histological and other techniques to trace afferent fibrous pathways from the hindbrain, leading to widespread investigations of the corona radiata, centrum semiovale, corpus callosum, and other structures comprising white matter. Others, including the Swiss pathologist Johann Jakob Wepfer (1620-1695), carefully described cases that anticipated localization debates centuries later; for instance, in one postmortem examination of an elderly woman with apoplectic symptoms, Wepfer noted that her sudden loss of speech production, sensation, and motor abilities was likely related to a cavity in left cortex.

The 18th century was a time of marked increases in physiological knowledge, often combined with searching conjecture. Emanuel Swedenborg (1688-1772), following Newton, proposed that nerves operate by vibration, with differences in 'tremulation' and frequency affording gross motor control. Albrecht von Haller (1708-1777) proposed that neurons operate by the nearinstantaneous flow of an invisible albuminous 'nervous liquor' or 'nerve juice'-a hypothesis that Samuel Soemmerring (17551830) later developed into a transcendental physiology, which was effectively a new twist on an old, ventricular, seat-of-the-soul account (and widely trounced by philosophers like Kant, Lichtenberg, Goethe, and von Humboldt). These hypotheses notwithstanding, Swedenborg distinguished between the role of motor cortex in voluntary movements, associating autonomic or habitual behaviors with subcortical parts. And von Haller helped establish experimental methods in neurophysiology by stimulating nerves of live animals and observing behavioral consequences; he also discovered that density of neuronal innervation is related to sensory capacity and demonstrated that cerebellar damage need not lead to death or respiratory failure.

Another proposal-radical at the time-came in the mid-18th century, when various scientists and other 'natural philosophers', following the advent of Leyden jars for storing charges, suggested that nervous activity may involve electrical conductance. Stephen Hales (1677-1761) is reported to have been among the earliest to reckon 'animal spirits' as spark-like, along with Jean Jallabert (1712-1768), who used electricity's ability to stimulate muscles, and Eusebio Sguario (1717-1764), who presciently advocated using the hypothetical-deductive method to test the hypothesis of neuromuscular electrical conductance.

\section{Modern}

Histories of behavioral neurology almost invariably trace the modern period to the lecture tours of Franz Joseph Gall (1758-1828) and his understudy, Johann Gaspar Spurzheim (1776-1832) at the beginning of the 19th century. In part, this is because of the interesting confluence of Gall's radical empiricist philosophy; his physiognomy and radically false phrenology, which were developed in a series of self-promotional roadshow exhibitions; his fierce debates with establishment academics; and his theoretical developments in localization. This 'standard story' omits the many philosophical and scientific influences on Gall. One immediate 
predecessor was Johann Gottfried von Herder (1744-1803), whose Vom Erkennen und Empfinden der Menschlichen Seel and Ideen zur Philosophie der Geschichte der Menschheit attempted to harmonize the competing philosophies of materialistic monism and mindbody dualism. In Herder, Gall found a philosophical framework within which to fathom his experiences as medical student-particularly, during his time at Vienna's Narrenturm, which offered opportunities to relate postmortem dissections with previous clinical observations of psychiatric patients' behaviors. Another predecessor was Johann Mayer (1747-1801), who argued for a program, using forensic autopsies, to predict specific behavioral and cognitive deficits from particular damages. Mayer directly challenged the holism of von Haller, who had lent his name to the thesis that the brain functions as a whole without distinct component operations, and this challenge opened the way for Gall \& Spurzheim's localizationism (Finger \& Eling, 2019).

Gall ascribed a panoply of $>27$ different mental faculties and aptitudes, each governed by particular loci in the semi-organized array of the cerebral cortex, and connected to white matter tracts by projection and association fibers. But his serious work attracted scores of critics, and was compromised by the collapse of phrenology. Holists, like Luigi Rolando (1773-1831) and Marie Jean Pierre Flourens (1794-1867), dismissed the search of specific 'seats' for higher-order functions and movements of musculature in the cortex. Rolando demonstrated that galvanic current to the cerebellum induces convulsions, while lesions perturb motor control, and Flourens's ablation and decerebration experiments in 1824 eroded confidence in cerebral localization.

Jean Baptiste Bouillaud (1796-1881) responded by postulating multiple movement centers, including in the cortex, and claimed that the faculty of articulate language had its seat in the brain's anterior lobules. Following Marie François Xavier Bichat's (1777-1802) doctrine of the functional symmetry of paired organs in his Anatomie Générale Appliquée à la Phsiologie et à la Médecine, Bouillaud (1825) considered that articulate language is seated in both frontal lobes. He supported this claim by establishing correlations between the presence (or absence) of speech disturbances in patients, as recorded in clinical histories, and the presence (or absence) of anatomical lesions in the anterior parts of the brain, as reported in post-mortem examinations. Bouillaud's 'new organology' remained a marginal initiative for decades, owing to three factors: the general discredit of the old organology of Gall, the lack of a clinical characterization of the 'loss of speech' syndrome, and the fragmentary and disputable character of the collected clinical evidence.

Aphasiology, as a research program, emerged in the French medical scene at the beginning of the 19th century, with the integration of Gall's doctrine of the plurality of cerebral organs and Bouillaud's method of correlating clinical deficits and pathology. In the Parisian Societé d'Anthropologie, a debate emerged over whether brain and skull size positively correlates with intelligence. In April 1861, Ernest Aubertin (1825-1893), who was married to Bouillaud's daughter and worked with him at the Charité, suggested that they ignore such debates and instead return to the localization of neurophysiological function. For Aubertin, anterior lobe development would be a more meaningful correlate of intelligence, residing in the frontal lobes where our higher human functions were seated.

Shortly after Aubertin's presentation, in which he argued in favor of localizing speech functionality to the anterior lobes, Pierre Paul Broca, who was president of the Societé and surgeon of the Bicetre Hospital, found a dying patient named Louis Victor Leborgne, who for 21 years had lost the ability to produce articulated speech. Broca noticed the case's potential as a breakthrough in the cerebral localization of language. Broca (1861a) reported that Leborgne could only pronounce the single syllable tan repeated twice at a time. Although the extent of intelligence was undetermined, Leborgne understood almost everything communicated to him, and made accurate numerical responses (by gesturing); the muscles corresponding to phonation and articulation were not paralyzed. Broca named this singular symptomatology 'aphemia': the loss of speech without the paralysis of the organs of articulation and without destruction of the intellect (renamed 'aphasia' by Armand Trousseau in 1864). At the autopsy following Leborgne's death, Broca (1861a) reported that the left frontal lobe was softened extensively, that the convolutions of the orbital region preserved their shape, and there was a large cavity, 'capable of holding a chicken egg', filled with serous fluid, in the middle portion of the frontal lobe. Broca speculated that the original seat of the lesion was the third frontal convolution, such that the faculty of articulated language plausibly resides in that area (see Fig. 2). Broca's contribution was immediately well-received, and-although Marc Dax (1770-1837) originally discovered the correlation 25 years prior-Leborgne's case constituted the landmark exemplar of the cortical localization of function. Broca's clinical report was a detailed specification of the speech deficit, and his pathological findings discredited the orbital localization advanced by phrenologists. Finally, his discussion of cerebral convolutions and sulcal anatomy, rooted in Gratiolet's (1854) maps, was new and sophisticated.

In November 1861, Broca presented a second case of Lelong, an 84-year-old man capable of producing only five utterances: oui, non, toi (a mispronunciation of trois), toujours, and Lelo (a mispronunciation of his surname). At autopsy, Broca (1861b) found that Lelong's lesion was at the inferior frontal gyrus, as with Leborgne. In 1863, he presented eight more similar cases of aphasia, in which lesions likewise congregated in the left cerebral hemisphere, which violated the physiological doctrine (advocated by Bichat, Bouillaud, and others) that two organs that are equal and symmetrical have the same attributes. In 1865, Broca withdrew his support for Bouillaud's hypothesis that speech is localized in both 'anterior' lobes, suggesting instead that the center for articulated language was in the third left frontal convolution only (now known as 'Broca's area'). This cerebral dominance was explained, in turn, by the more precocious development of the left hemisphere. In 1906, upon review, Pierre Marie questioned whether the lesions were as precise and localized as Broca had reported, which provoked strong responses from localizationists like Joseph Jules Déjerine (1849-1917) and Christofredo Jakob (1866-1956), a German-Argentinian neuropathologist. Today, we know that the lesions extended cortically and subcortically into medial regions of the brain (Dronkers et al., 2007).

John Hughlings Jackson, considered to be the 'father of English neurology' (Critchley \& Critchley, 1998), was another early advocate of the 'clinic-anatomical correlation method'. Jackson confirmed the importance of Broca's area for language production, reporting speech disturbances of 31 patients with left hemisphere damage $(1863,1865)$. However, he warned that localization 


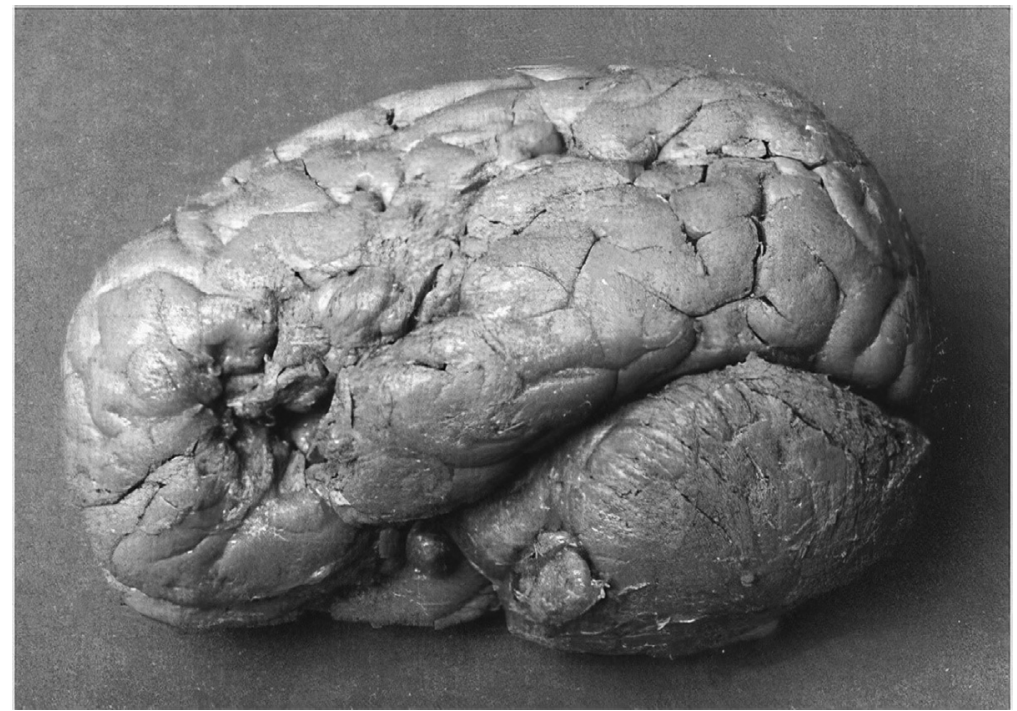

Figure 2 Postmortem photograph of the brain of Leborgne. Excerpted from Dronkers et al.(2007: 1436).

of symptom need not imply localization of function: 'to locate the damage which destroys speech and to locate speech are two different things' (1874: 81). Jackson's main contribution to clinical neurology was his work on epilepsy, which he defined as an 'occasional, sudden, excessive, rapid, and local discharge of gray matter' (1873: 3). He noticed for the first time the predictable temporal sequence of muscle spasms or sensations in unilateral seizures (now known as 'Jacksonian epilepsy'), which indicated that motor areas of the cortex must be organized somatotopically. In 1870, Gustav Fritsch (1838-1927) \& Eduard Hitzig (1838-1907) performed stimulation and lesion experiments that demonstrated cortical specialization of motor function in dogs, confirming Jackson's hypothesis.

The impact of Broca's discoveries in the German scientific community was attenuated by the influence of Helmholtz's physiological program, which emphasized the mapping of smaller subcomponent functions onto physiological processes (Roth, 2014). Carl Wernicke's (1848-1904) monograph Der Aphasische Symptomenkomplex paved the way for accepting higher function localization in the cortex. By Wernicke's connectionist approach, multiple interconnected cortical regions are necessary for orchestrating higher psychological functions, including language:

only the most elementary psychic functions can be assigned to defined areas of the cortex $[\ldots]$ Everything that goes beyond these simple functions $[\ldots]$ is the achievement of the fiber tracts which connect the different regions of the cortex to each other, the so-called association system of Meynert. (1874: 34-35)

The significance of Theodor Meynert's (1833-1892) work is vast. He recognized that the cortex could be subdivided into posterior sensory and anterior motor parts, which are interconnected by projection fibers (connecting cortical to subcortical areas), association fibers (interconnecting cortical regions), and commissural fibers. It was Meynert who first showed that some kind of aphasia (bizarre unintelligible speech patterns with difficulties in language comprehension) could occur following upper left temporal lobe lesions (Geschwind, 1974). From this, Meynert concluded that the temporal lobes contained a 'sound field' that was responsible for speech recognition.

Wernicke considered that his own 1874 monograph followed 'almost automatically' from Meynert's writings and dissections. In its first part, Wernicke introduced a schematic representation of a psychic reflex on the pattern of a reflex arc. In his model, any sensory stimulus $E$ leaves a memory image $O$ in the sensory part of the brain (i.e., the occipitotemporal lobes). Similarly, bodily movements leave a motor image $F$ in the motor (anterior) part of the brain, which can precipitate a movement $B$. The psychic reflex arc is completed by associative fiber tracts connecting sensory (occipital-temporal) and motor (anterior) areas in the brain.

In the monograph's second part, Wernicke introduced his psychic reflex arc schema for language processing, which became the foundation for his concept of the aphasic symptom-complex. In the schema, Wernicke distinguished between motor and sensory component centers and the connections between them. At one side, pure cases of Broca's aphasia, or 'motor aphasia', were considered to be the result of destruction or impairment of motor components for speech, located in the frontal lobes (i.e., in the third left frontal gyrus), precisely where one would expect to find memories for motor images of words. On the other side, a second kind of aphasia, 'sensory aphasia', was produced by the destruction or impairment of the sensory component for speech, located in the leftside of the temporal lobe (so-called 'Wernicke's area'), near the auditory area. The sensory center for speech contained memories for the acoustic image of words. Those patients with pure Wernicke's aphasia showed more fluent speech and larger vocabularies than Broca's patients, but they exhibited difficulties comprehending speech because they could not recognize the acoustic images of 


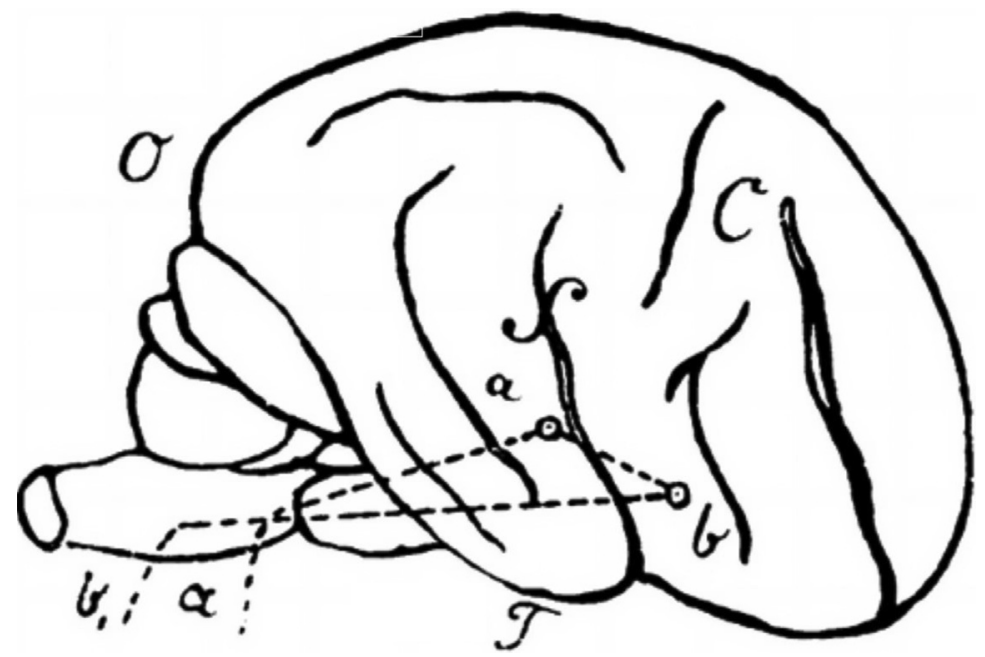

Figure 3 The model from Wernicke (1874: 19).

words. These patients could not monitor their speech output, producing unintelligible or bizarre speech, marked by what Adolf Kussmaul (1822-1902) called 'paraphasic' errors, mispronunciations, word confusions, transpositions, and neologisms. In the third part of his monograph, Wernicke presented several clinical cases of this new kind of aphasic disorder. Wernicke (1874) concluded, '[t]he demonstration of these two types [pure motor aphasia and pure sensory aphasia] must be regarded as conclusive proof of the existence of two anatomically separate language centers'. In his well-known cartoon representation of his model, reproduced in almost every medical textbook, $\alpha$ represents the acoustic nerve that terminates in the temporal sensory language center $(a)$. This center is connected to the frontal motor language center $(b)$, extending to brainstem areas (Fig. 3). Given that the model postulated a direct pathway from Wernicke's area to Broca's area, Wernicke predicted the existence of a third type of aphasia, called 'conduction aphasia', in which damage of the system of connecting fibers produced peculiar symptomatology. In patients with conduction aphasia, both speech comprehension and speech production remain intact to some extent. However, damage to the connection between the centers produced failures in repetition, due to the disruption of information transferring from the word listened to the word spoken. The patients exhibited very hesitant spontaneous speech, with abundant paraphasic errors that they consciously try to correct, approaching gradually to their target (i.e., the conduit d'approche phenomenon). Wernicke considered that the relevant connecting fibers were constituted by the arcuate fasciculus around the insula. Current opinion holds that conduction aphasia may not be caused by pure white matter lesions, with the posterior part of the left planum temporale hypothesized to be the critically damaged area in patients with conduction aphasia (Rutten, 2017).

Wernicke's innovative integration of theoretical model-making and the clinico-pathological method has been referred as the 'connectionist' or 'associationist' approach. This approach was developed by Ludwig Lichtheim (1845-1928), Hugo Liepmann (1863-1925), and Heinrich Lissauer, (1861-1891), among others in Germany, and by Déjerine in France. Lichtheim (1885) amended Wernicke's model with a separate center for concept formation. This new component was thought to be a knowledge network of associations that contained the concepts to which words refer (Roth, 2014). This addition enabled him to describe two new types of aphasia: namely, transcortical sensory aphasia, produced by the disrupted connection of Wernicke's area to the concept center, and transcortical motor aphasia, produced by a disconnection of Broca's area and the concept center. Liepmann (1898) provided a connectionist account of deficiencies in the ability to plan and execute complex learned movements (apraxia), in the absence of primary sensory and motor deficits. He distinguished several kinds of apraxia (idio-kinetic, ideational, limbkinetic), and proposed an anatomical model by which the left hemisphere is dominant for complex movement control and the right hemisphere depends on the left to control actions of the left hand. Lesions in the left parietal lobe would lead to bilateral apraxia, while lesions of the corpus callosum pathway from left to right would result in apraxia of the left hand. Lissauer (1890) provided the first connectionist explanation of a deficit in simple visual recognition of commonplace objects, known as 'visual agnosia'. He distinguished between apperceptive and associative subtypes of agnosia. The first kind would be the effect of lesions primarily located at the visual cortex itself, whereas associative agnosia would be produced by disruptions of transcortical pathways connecting the visual percept with wider associations across various modalities. In later years, Wernicke also speculated about the possibility of a brain region responsible for the encoding of written words (Wickens, 2014). Based on the clinic-pathological method, Déjerine $(1891,1906)$ proposed the first connectionist explanation of pure alexia, proposing a 'visual verbal' center, a memory of visual images of words, located in the left angular gyrus (See Fig. 4).

A negative attitude toward the connectionist approach dominated the beginning of the 20th century. In his 1926 monograph, Henry Head (1861-1940) derisively referred those who endorsed this approach as 'diagram makers' for their tendency to illustrate their models with diagrams of centers in the brain and connections between those centers. The main protagonists of psychoanalysis, anti-mechanism, behaviorism, and Gestalt and experimental psychology adopted more holistic explanations implicating the whole 


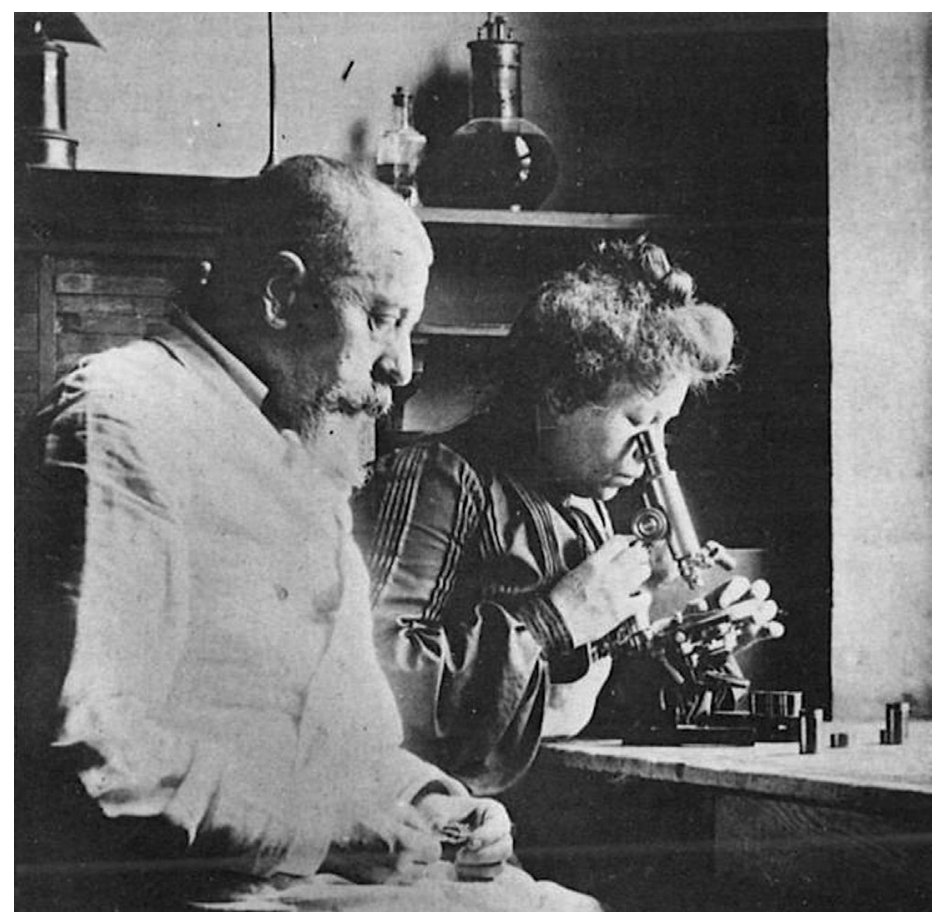

Figure 4 Joseph Jules Déjerine and his wife Augusta Déjerine-Klumpke.

brain in higher-level complex functions. Theoretical movements notwithstanding, some excellent clinical studies related to localization of function appeared during this period. While seeking new treatments for severe epilepsy, Wilder Penfield (1891-1976) developed a neurosurgical procedure in which he surgically exposed the brain of fully conscious patients (under local anesthesia), stimulated different locations of the cortex with electrodes, and registered the patient's feelings, sensations, movements, and memories, in order to identify the damaged tissue responsible for the seizures (Penfield \& Boldrey, 1937). This method allowed him to chart the functional somatotopic organization of the somatosensory and motor cortices, illustrated by the famous sensorimotor homunculi (Penfield \& Rasmussen, 1950).

\section{Contemporary}

During the first half of the 20th century, neurology and psychiatry developed in isolation, as neurology had abandoned behavior while psychiatry abandoned the brain. The schism between neurology and psychiatry was not there in the late 19th century, however. In fact, the concept of nervous diseases originated in Britain during the 17th and 18th centuries as a reaction against traditional Galenism (López Piñero, 1983). William Cullen (1710-1790) introduced the term neuroses as affections of sense and motion without fever or evidence of local disease. The term was applied to disorders now classified as neurologic, such as paralysis, and others considered psychiatric, such as melancholia (Reynolds, 1990). In 1817, James Parkinson published a report of several cases of shaking palsy (paralysis agitans), describing the difficulties with walking and posture associated with 'involuntary tremulous motion'. In 1872, George Huntington described a hereditary type of chorea and established the principle of direct inheritability of neurologic disorders (Martin, 2002). In France, Charcot and his disciples made descriptions of multiple sclerosis and other nerve disorders. Throughout the 19th century, the prominent German and Austrian school of neuropsychiatry, headed by Wilhelm Griesinger (1817-1868) in Berlin and Meynert in Vienna, directed the practice of the discipline toward the search for the biological basis of psychiatric diseases. William Gowers' Manual of Diseases of the Nervous System (1886) illustrated and classified a variety of nervous diseases discovered by histological methods and clinic-pathological correlations. In the sixth edition of his textbook Compendium der Psychiatrie from 1899, Emil Kræpelin (1856-1925) introduced the dichotomy between manic-depressive psychosis and dementia praecox - the latter renamed as 'schizophrenia' by Eugen Bleuler in 1908-and set the foundation of modern systems of psychiatric classification. Kræpelin's student, Alois Alzheimer, reported the case of Auguste D., a 51-year-old woman from Frankfurt who had exhibited progressive memory impairment, disorientation, hallucinations, and psychosocial incompetence in 1906. Histopathologically, the patient was found to have arteriosclerotic changes, senile plaques, and neuro-fibrillary tangles. Kræpelin introduced the eponym Alzheimer's disease in 1910. Despite these advancements, the neuropsychiatric program was not immediately successful in establishing correlations between the clinical symptoms of psychiatric diseases and their purported pathologicalanatomical markers. This failure partially explains the progressive separation of neurology and psychiatry as autonomous disciplines in the early 20th century; however, the growth of psychoanalysis and psychodynamic psychiatry ultimately forged the divide. 
After the Great War, the spotlight of psychiatry shifted to the United States, where the psychoanalytic movement was flourishing. Freudian psychiatrists aimed to redirect the focus of the discipline from psychosis, as manifested within the asylum, to the psychoneuroses, as manifested in everyday life (Freud, 1901/1989). Neuroses were to be explained by subconscious psychological factors, on the conviction that neurotic symptoms were caused by repressed childhood sexual drives, memories, or fantasies that conflicted with psychological or social demands. A psychotherapy was recommended that emphasized dream interpretation, free association, and the elaboration of the analyst-patient relationship itself. At the heights of psychoanalytic dominance, some psychiatrists attempted psychodynamic explanations of psychotic diseases. Frieda Fromm-Reichman (1948) described schizophrenia as a radical form of distrust and resentment, which she attributed to childhood experiences of rejection by 'schizophrenogenic mothers'. Such zany extremes were exceptional, however, since an organic versus functional dichotomy was tacitly endorsed both by neurologists and psychiatrists, implying a division of labor in which neurologists should limit themselves to the search of anatomical causes of neurological alternations, and psychiatrists should focus on the psychodynamic causes of mental disturbances. For many decades, scientific/academic societies, training programs, and authoritative textbooks reinforced this divide (Shorter, 1997).

In the United States, the bridges between neurology and psychiatry began to be reconstructed in the late 1960s, with the reinterpretation of major mental illnesses as biologically-based diseases. Against the idea of schizophrenia as an environmental disease caused by negligent motherhood, Danish studies comparing the prevalence of mental illness in the biological and adoptive families of adopted schizophrenics found a higher prevalence of schizophrenia-related illness among the biological relatives of adopted schizophrenics, but not among their adoptive relatives (Kety et al., 1968). This finding strongly supported a genetic transmission of vulnerability to schizophrenia, and suggested the importance of studying both genetic and environmental influences. Following the emergence of molecular neuroscience, the discovery of new psychopharmaceuticals, and the neuroimaging revolution, conditions like schizophrenia, affective and anxiety-related disorders, autism, and many others came to be recognized as psychiatric disorders with underlying neurological or anatomical abnormalities with biochemical profiles (Post, 2000).

This historical trend toward 'closing the great divide' between neurology and psychiatry (Price et al., 2000) underlies the rapprochement and recent consolidation of these medical fields, which depended not only on the revival of biological approaches to psychiatric disorders but also on the development of behavioral neurology as a medical subspecialization within neurology (Arciniegas et al., 2013). Consensus has it that contemporary behavioral neurology was inaugurated with the publication of Norman Geschwind's (1926-1984) two-part study, 'Disconnexion syndromes in animals and man', which became the manifesto of behavioral neurology. Geschwind expanded upon Wernicke's ideas and synthesized the available clinical evidence to articulate a specifically disconnectionist framework for higher function deficits (see Fig. 5).

Geschwind made two new advancements. Firstly, he resurrected a then-forgotten neuroanatomical principle articulated by Paul Flechsig (1847-1929). In his myelogenetic studies of human cortex, Flechsig (1901) inferred an anatomical rule according to which primary sensory areas have no direct neocortical connections between them. There is no long association system directly connecting those early myelinated zones, but all connections between primary sensory areas are indirect; they pass through immediately adjacent parasensory areas, or 'association' areas. Whereas Flechsig intended the rule to apply to sensory cortex only, encompassing motor cortex and connections between the hemispheres, Geschwind generalized it. From his perspective, association cortex is a relay station between primary motor, sensory, and limbic areas. Furthermore, for Geschwind, the evolution of association areas underlay the evolution of higher functions (Catani \& ffytche, 2005). In humans, the emergence of a higher-order association area in the inferior parietal lobe (angular and supramarginal gyri) permitted visual, auditory, and somatosensory associations freed from sensorylimbic associations, which may be prerequisite for language.

Secondly, Geschwind (1965) elaborated a broader view of disconnections, in which even pure lesions of an association region could cause a disconnection syndrome. For Wernicke, disconnection syndromes implied a white matter lesion; but for Geschwind,

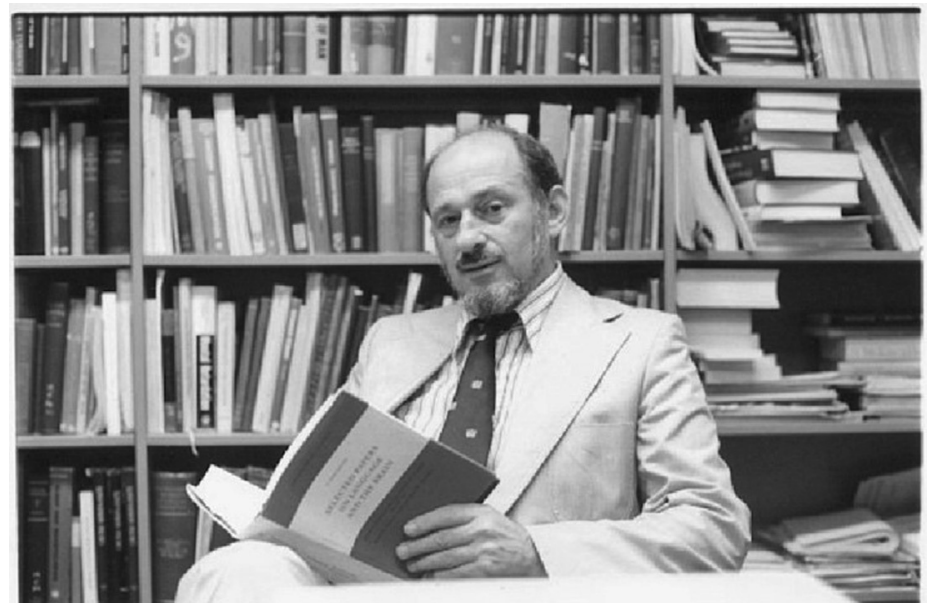

Figure 5 Norman Geschwind. 
large lesions in either association cortex or white matter tracts should be considered 'disconnexion lesions' to the extent that they disconnect primary sensitive or motor areas from other regions of the cortex, whether ipsilateral or contralateral. With this new characterization of disconnection lesions, Geschwind developed a unified connectionist account of an impressive catalog of higher function disorders.

Geschwind distinguished three different types of disconnection syndromes (Catani \& ffytche, 2005). Firstly, there are disconnections between sensory areas and the limbic system. Disconnection of somesthetic areas from the limbic system result in pain asymbolia. Disconnection of the primary auditory cortex from the limbic system result in verbal learning impairment. Secondly, there are disconnections between sensory areas and Wernicke's area. Geschwind distinguished between four modality-specific language deficits: (i) tactile aphasia, following disconnections between Wernicke's area and somesthetic areas; (ii) pure word deafness (Liepmann, 1898), following disconnections between Wernicke's region and primary auditory cortex; (iii) pure alexia, which Déjerine described as a disconnection between visual areas and the supramarginal angular gyrus; and (iv) visual agnosia, which Geschwind construed as an indirect disconnection of visual areas from Wernicke's region via the angular gyrus. Thirdly, there are disconnections between sensory areas and motor cortex. As Liepmann (1898) described, disconnections of hand motor cortex from posterior sensory areas result in apraxia; disconnections of Broca's center from Wernicke's center cause conduction aphasia, as envisaged by Wernicke. Concerning interhemispheric disconnections, Geschwind endorsed Déjerine's and Liepmann's accounts of pure alexia and callosal apraxia, respectively.

Geschwind's connectionist framework became paradigmatic. With Harold Goodglass (1920-2002), Edith Kaplan (1924-2009), and others, Geschwind established the Aphasia Research Center at the Boston Veteran Administration Hospital, which became the epicenter of the behavioral neurology revolution in the 1970s. A generation of behavioral neurologists passed through Geschwind's research center, including Frank Benson, Marsel Mesulam, and Antonio Damasio. It is widely acknowledged that 'virtually all behavioral neurologists can trace their intellectual origin directly or indirectly to Geschwind' (Filley, 2016). Geschwind introduced the phrase behavioral neurology in 1972 at an American Association of Neurology meeting, and members organized the Behavioral Neurology Society (BNS) a decade later, with several textbooks promptly appearing (Pincus \& Tucker, 1974; Mesulam, 1985). Ironically, Geschwind's framework diminished in prominence during 'the decade of the brain' (1990s), as two general considerations obtained scientific acceptance. Firstly, association cortex is now known to be, not a homogenous relay station, but to have specialized functional roles (Zeki et al., 1991). Secondly, the complexity of parallel, feedback, and distributed pathways between, and within, cortical territories became evident (Damasio, 1989; Damasio et al., 2004).

Toward the end of the millennium, new tools and methods swiftly accelerated progress in both cognitive neuroscience and behavioral neurology (Bickle, 2019). Computed tomography (CT) enabled the localization of many aphasia syndromes diagnosed by standardized clinical methods. Positron emission tomography (PET) allowed for identification of different visual pathways in the visual association cortex in humans, improving the explanation of visual agnosia syndromes (Sergent et al., 1992). PET imaging tracers that correlate $\beta$-amyloid deposition in the brain have been widely used to develop biomarkers of Alzheimer's disease, years before the onset of clinical symptoms. Magnetic resonance imaging (MRI) and diffusor tensor imaging improved the visualization of white matter tracts, providing for more sophisticated conceptions of white matter dementia (Filley et al., 1988). Despite ongoing controversies, functional MRI (fMRI) has become the essential tool for those interested understanding the functional correlates of behavior and disease.

As a result of these tool developments in imaging, a new framework for behavioral neurology surfaced-large-scale distributed neural networks - which aims for balance between specialization of cortical areas and corticocortical connectivity. This network approach evolved from the convergence of lesion methods and the imaging revolution from the 1980s, which allowed scientists to non-invasively explore patients' damaged brain areas in vivo. Five anatomically individuated large-scale networks became the relevant foci for medical/psychiatric practice: a limbic network for memory, emotion, and motivation; a ventral occipito-temporal network for object recognition; a dorsal parieto-frontal network for spatial orientation; a perisylvian network for language; and a prefontal network for attention, executive function, and comportment (Mesulam, 1999, 2000). Based on neuropathology, neuroimaging, and evidence from transgenic animal models, some researchers have proposed that human neurodegenerative diseases may relate to dysfunction in these large-scale brain networks (Seeley et al., 2009). An early example of this trend has been the discovery of primary progressive aphasia, a syndrome of relatively focal cerebral degeneration with a predilection for the left perisylvian region, without the generalized cognitive and behavioral disturbances of dementia (Mesulam, 1982). The study of frontal lobe function and disease has become another epicenter of research, with raised scientific and social awareness of dementia as a public health issue. Behavioral disorders such as apathy and disinhibition were associated with tissue loss in the ventral portion of the right anterior cingulate cortex and adjacent ventromedial superior frontal gyrus, the right ventromedial prefrontal cortex, the right lateral middle frontal gyrus, the right caudate head, the right orbitofrontal cortex and the right anterior insula (Rosen et al., 2005). These discoveries boosted the study of the context-modulated, complex, integrated large-scale network that underlies social cognition (Kennedy \& Adolphs, 2012). More recently, PET and fMRI studies have identified widespread neural networks, defined by functional connectivity, and associated with behavioral functions. The first neural network characterized this way has been the default mode network (DMN) (Raichle et al., 2001). Buckner et al. (2005) demonstrated a remarkable correlation between DMN activity patterns in cortical regions in young adults and the topography of amyloid deposition in elderly AD patients. Network analysis and neuroimaging technologies revolutionized both the theoretical landscape and the clinical practice of behavioral neurologists, opening new avenues for diagnosis and treatment. 


\section{Back to the Future}

As a branch of medicine that long predates the scientific revolution, behavioral neurology has a rich history. However, it is also enjoying a re-emergence, owing to the renewal of neuropsychiatry and neuropsychology in the second half of the 20th century, new theoretical paradigms, new mathematical and computational tools, and experimental methods. Consequently, behavioral neurology is sometimes ambivalently described as either an old and venerable practice, or else a new discipline undergoing an exciting period of explosive growth (Benson, 1993). This latter description becomes increasingly salient as one refocuses from the medical objectives of diagnosis and treatment to renewed interest in the scientific principles of localization and decomposition and other forms of bottom-up reasoning (Schaffner, 1993). Decomposition and localization are experimental and analytical strategies used in the service of explaining phenomena such as seizures, dyskinesias, disconnection syndromes, and other neurobehavioral conditions, and are two of the cornerstones of what has come to be called 'New Mechanism' in contemporary philosophy of science and medicine (see Bechtel \& Richardson, 1993; Thagard, 1998, 2006; see also Glennan \& Illari, 2017). The basic idea is for researchers to model the causal relationships leading to a target phenomenon, such that it can be pinned down to a particular system's activities (phenomenal modeling); to take the system apart apart-either actually or analytically-and determine the component parts (structural decomposition) of the system or the component operations (functional decomposition) of its activities; and to assign these parts and operations (localization) while exploring their constitutive organization (systemic analysis). The principles of the New Mechanists are also those used by Aubertin, Wernicke, and Déjerine in the 19th century, and that touch on older philosophical foundations from Gall, Spurheim, and Dax in the 18th century; they are even continuous with the pioneering efforts of early 17 th century mechanists and clinicians like Stenonius and Wepfer.

\section{References}

Alzheimer, A., 1906. Uber einen eigenartigen schweren erkrankungsprozess der hirninde. Neurologisches Centralblatt 25, 1134. Arciniegas, D., Anderson, C., Filley, C. (Eds.), 2013. Behavioral Neurology and Neuropsychiatry. Cambridge University Press.

Bechtel, W., Richardson, R., 1993. Discovering Complexity: Decomposition and Localization as Scientific Research Strategies. Princeton University Press.

Benson, F., 1993. History of behavioral neurology. Neurologic Clinics 11 (1), 1-8.

Benton, A., Joynt, R., 1960. Early descriptions of aphasia. Archives of Neurology 3 (2), 205-222.

Bichat, X., 1801. Anatomie Générale Appliquée à la Phsiologie et à la Médecine. Brosson and Chaudé

Bickle, J., 2019. Linking mind to molecular pathways: the role of experiment tools. Axiomathes 29 (6), 577-597.

Bonet, T., 1679. Sepulchretum Sive Anatomica Practica Ex Cadaveribns Morbo Denatis. Chouet.

Bouillaud, J., 1825. Recherches cliniques propres à démontrer que la perte de la parole correspond à la lésion des lobules antérieurs du cerveau, et à confirmer l'opinion de M. Gall, sur le siège de l'origine du langage articulé. Archives Générale de Médecine 8, 25-45.

Breasted, J., 1930. The Edwin Smith Surgical Papyrus: Published in Facsimile and Hieroglyphic Transliteration with Translation and Commentary in Two Volumes. University of Chicago Press

Broca, P., 1861a. Remarks on the seat of the faculty of articulated language, following an observation of aphemia (loss of speech). Bulletin de la Sociéte Anatomique 6, 330-357.

Broca, P., 1861b. Nouvelle observation d'aphémie produite par une lésion de la moitié postérieure des deuxième et troisième circonvolution frontales gauches. Bulletin de la Société Anatomique 36, 398-407.

Broca, P., 1863. Localisations des fonctions cérébrales: siège de la faculté du langage articulé. Bulletin de la Société d'Anthropologie 4, 200-208.

Broca, P., 1865. Sur le siège de la faculté du langage articulé. Bulletin de la Société d'Anthropologie 6, 337-393.

Buckner, R., Snyder, A., Shannon, B., LaRossa, G., Sachs, R., Fotenos, A., Sheline, Y., Klunk, W., Mathis, C., Morris, J., Mintun, M., 2005. Molecular, structural, and functional characterization of Alzheimer's disease: evidence for a relationship between default activity, amyloid, and memory. Journal of Neuroscience 25 (34), $7709-7717$.

Catani, M., ffytche, D., 2005. The rises and falls of disconnection syndromes. Brain 128 (10), 2224-2239.

Critchley, M., Critchley, E., 1998. John Hughlings Jackson: Father of English Neurology. Oxford University Press.

Damasio, A., 1989. Time-locked multiregional retroactivation: A systems-level proposal for the neural substrates of recall and recognition. Cognition 33 (1), 25-62.

Damasio, H., Tranel, D., Grabowski, T., Adolphs, R., Damasio, A., 2004. Neural systems behind word and concept retrieval. Cognition 92 (2), 179-229.

Déjerine, J., 1891. Sur un cas de cécité verbale avec agraphie suivi d'autopsie. Mémoires de la Société de Biologie 3, $197-201$.

Déjerine, J., 1906. L'aphasie motrice: sa localisation et sa physiologie pathologique. La Presse Médicale 57, 453-457.

de Luzzi, M., 1316/1475. Anatomia Mundini. Petrus Maufer.

Descartes, R., 1637. Discours de la Methode pour Bien Conduire sa Raison, et Chercher la Verite dans les Sciences. Maire.

Descartes, R., 1662. De Homine. Leffen and Moyard.

Descartes, R., 1664. L'Homme. Angot.

Dronkers, N., Plaisant, O., Iba-Zizen, M., Cabanis, E., 2007. Paul Broca's historic cases: high resolution MR imaging of the brains of Leborgne and Lelong. Brain 130 (5), 1432-1441.

Feinberg, T., Farah, M., 1997. Development of modern behavioral neurology and neuropsychology. In: Behavioral Neurology and Neuropsychology. McGraw-Hill, pp. 3-23.

Fernel, J., 1542. De Naturali Parte Medicinæ. Simon de Colines.

Fernel, J., 1554. Medicina. Andreas Wechel.

Filley, C.M., 2016. The history of behavioral neurology. In: Barr, W., Bieliauskas, L. (Eds.), Oxford Handbook of History of Clinical Neuropsychology. Oxford University Press, pp. 1-28.

Filley, C., Franklin, G., Heaton, R., Rosenberg, N., 1988. White matter dementia: clinical disorders and implications. Neuropsychiatry, Neuropsychology, and Behavioral Neurology 1 (4), 239-254.

Finger, S., Eling, P., 2019. Franz Joseph Gall: Naturalist of the Mind, Visionary of the Brain. Oxford University Press.

Flechsig, P., 1901. Developmental (myelogenetic) localisation of the cerebral cortex in the human subject. Lancet 158 (4077), 1027-1030.

Freud, S., 1901/1989. The Psychopathology of Everyday Life. Norton.

Fromm-Reichmann, F., 1948/1976. Bemerkungen zur behandlung der schizophrenie in der psychoanalytischen psychotherapie: heilung durch wiederherstellung von vertrauen. In:

Matussek, P. (Ed.), Psychotherapie Schizophrener Psychosen. Hoffmann und Campe, pp. 34-52.

Galenus, /1956. De Anatomicis Administrationibus Libri Novem, Trans. C. Singer. Oxford University Press.

Galenus, /1968. De Usu Partium, Trans. M. T. May. Cornell University Press. 
Garber, D., 2002. Descartes, mechanics, and the mechanical philosophy. Midwest Studies in Philosophy 26 (1), 185-204.

Geschwind, N., 1965. Disconnexion syndromes in animals and man, parts I and II. Brain 88 (2/3), 237-294, 585-644.

Geschwind, N., 1974. Selected Papers on Language and the Brain, Eds. Cohen, R. \& Wardofsky, M. Reidel

Gleason, M., 2009. Shock and awe: the performance dimension of Galen's anatomy demonstrations. In: Gill, C., Whitmarsh, T., Wilkins, J. (Eds.), Galen and the World of Knowledge. Cambridge University Press, pp. 85-114.

Glennan, S., Illari, P. (Eds.), 2017. Handbook of Mechanisms and Mechanical Philosophy. Routledge.

Gowers, W., 1886. A Manual of Diseases of the Nervous System: Diseases of the Spinal Cord and Nerves. Churchill.

Gratiolet, P., 1854. Mémoire sur les Plis Cérébraux de l'Homme et des Primates. Bertrand.

Gross, C., 1987. Early history of neuroscience. In: Adelman, G. (Ed.), Encyclopedia of Neuroscience. Birkhäuser, pp. 843-847.

Head, H., 1926. Aphasia and Kindred Disorders of Speech. Cambridge University Press.

Hughlings Jackson, J., 1863. Suggestions for Studying Diseases of the Nervous System on Professor Owens' Vertebral Theory. Lewis.

Hughlings Jackson, J., 1873. On the anatomical, physiological, and pathological investigations of epilepsies. West Riding Lunatic Asylum Medical Reports 3, 315-349.

Hughlings Jackson, J., 1874. On the nature of the duality of the brain. Medical Press and Circular 17, 19-21.

Kennedy, D., Adolphs, R., 2012. The social brain in psychiatric and neurological disorders. Trends in Cognitive Sciences 16 (11), 559-572.

Kety, S., Rosenthal, D., Wender, P., Schulsinger, F., 1968. The types and prevalence of mental illness in the biological and adoptive families of adopted schizophrenics. Journal of Psychiatric Research 6 (1), 345-362.

Koob, G., Le Moal, M., Thompson, R., Zola, S., 2010. History of behavioral neuroscience. In: Encyclopedia of Behavioral Neuroscience. Elsevier, pp. 27-44.

Lichtheim, L., 1885. On aphasia. Brain 7, 433-484.

Liepmann, H., 1898. Ein fall von reiner sprachtaubheit. In: Wernicke, K. (Ed.), Psychiatrische Abhandlungen. Schletter, 7(8), pp, 1-50.

Lissauer, H., 1890. Ein fall von seelenblindheit nebst einem beitrage zur theori derselben. Archiv fur Psychiatrie und Nervenkrankheiten 21, $222-270$.

Littré, E., 1973. Oeuvres Complètes d'Hippocrate. Baillière.

Lloyd, G., 1975. Alcmaeon and the early history of dissection. Sudhoffs Archiv 59 (2), 113-147.

Lopez-Piñero, J., 1983. Historical Origins of the Concept of Neurosis, Trans. D. Berrios. Cambridge University Press.

Luzzatti, C., Whitaker, H., 1996. Johannes Schenck and Johannes Jakob Wepfer: clinical and anatomical observations in the prehistory of neurolinguistics and neuropsychology. Journal of Neurolinguistics 9 (3), 157-164.

Marie, P., 1906. Revision de la question de l'aphasie: la troisième circonvolution frontale gauche ne joue aucun rôle spécial dans la fonction du langage. La Semaine Médicale 26, 241-247.

Martin, J., 2002. The integration of neurology, psychiatry, and neuroscience in the 21st century. American Journal of Psychiatry 159 (5), 695-704.

Mesulam, M., 1982. Slowly progressive aphasia without generalized dementia. Annals of Neurology 11 (6), 592-598.

Mesulam, M. (Ed.), 1985. Principles of Behavioral Neurology. Oxford University Press.

Mesulam, M., 1999. Neural substrates of behavior: the effects of focal brain lesions upon mental states. In: Nicholi, A. (Ed.), Harvard Guide to Psychiatry. Belknap Press, 3, pp, 101-103.

Mesulam, M., 2000. Large-score networds, association cortex, frontal systems, the limbic system, and hemispheric specializations. In: Principles of Behavioral and Cognitive Neurology. Oxford University Press, 2, pp, 1-120.

Penfield, W., Boldrey, E., 1937. Somatic motor and sensory representation in the cerebral cortex of man as studied by electrical stimulation. Brain 60 (4), 389-443.

Penfield, W., Rasmussen, T., 1950. The Cerebral Cortex of Man: A Clinical Study of Localization of Function. Macmillan.

Pestronk, A., 1988. The first neurology book: de Cerebri Morbis. Archives of Neurology 45 (3), 341-344.

Pevsner, J., 2019. Leonardo da Vinci's studies of the brain. Lancet 393 (10179), 1465-1472.

Pincus, J., Tucker, G., 1974. Behavioral Neurology. Oxford University Press,

Post, R., 2000. Neural substrates of psychiatric syndromes. In: Mesulam, M. (Ed.), Principles of Behavioral and Cognitive Neurology. Oxford Univesity Press, pp. 406-438.

Price, B., Adams, R., Coyle, J., 2000. Neurology and psychiatry: closing the great divide. Neurology 54 (1), 8-14.

Raichle, M., MacLeod, A., Snyder, A., Powers, W., Gusnard, D., Shulman, G., 2001. A default mode of brain function. Proceedings of the National Academy of Sciences 98 (2), $676-682$.

Reynolds, E., 1990. Structure and function in neurology and psychiatry. British Journal of Psychiatry 157 (4), 481-490.

Rocca, J., 2003. Galen on the Brain: Anatomical Knowledge and Physiological Speculation in the Second Century. Brill.

Rosen, H., Allison, S., Schauer, G., Gorno-Tempini, M., Weiner, M., Miller, B., 2005. Neuroanatomical correlates of behavioural disorders in dementia. Brain 128 (11), $2612-2625$.

Roth, H., 2014. We stand on the shoulders of giants: the golden era of behavioral neurology and its relevance to cognitive neuroscience today. In: Chatterjee, A., Coslett, H. (Eds.) The Roots of Cognitive Neuroscience: Behavioral Neurology and Neuropsychology. Oxford University Press, pp. 11-52.

Rutten, G.-J., 2017. The Broca-Wernicke Doctrine: A Historical and Clinical Perspective on Localization of Language Functions. Springer.

Seeley, W., Crawford, R., Zhou, J., Miller, B., Greicius, M., 2009. Neurodegenerative diseases target large-scale human brain networks. Neuron 62 (1), 42-52.

Sergent, J., Ohta, S., Macdonald, B., 1992. Functional neuroanatomy of face and object processing: a positron emission tomography study. Brain 115 (1), 15-36.

Schaffner, K., 1993. Discovery and Explanation in Biology and Medicine. University of Chicago Press.

Schalick, W., 2009. Neurological conditions in the European middle ages. In: Aminoff, M., Boller, F., Swaab, D. (Eds.), Handbook of Clinical Neurology: History of Neurology. Elsevier, 95, pp, 79-90

Schenck von Grafenberg, J., 1584. Observationes Medicæ de Capite Humano. Ex Officina Frobeniana.

Scurlock, J., Andersen, B., 2005. Neurology. In: Diagnoses in Assyrian and Babylonian Medicine: Ancient Sources. University of Illinois Press, pp. 284-344.

Shorter, E., 1997. A History of Psychiatry: From the Era of the Asylum to the Age of Prozac. John Wiley and Sons.

Steno, N., 1669. Discours de Monsieur Stenon sur L'Anatomie du Cerveau. Ninville

Solmsen, F., 1961. Greek philosophy and the discovery of the nerves. Museum Helveticum 18 (4), 169-197.

Thagard, P., 1998. Explaining disease: correlations, causes, and mechanisms. Minds and Machines 8 (1), 61-78.

Thagard, P., 2006. What is a medical theory? In: Paton, R., McNamara, L. (Eds.), Studies in Multidisciplinarity: Multidisciplinary Approaches to Theory in Medicine. Elsevier, pp. 47-62.

van der Velde, J., 1549. De Cerebri Morbis. Heinrich Petri.

van Wesel, A., 1543. De Humanis Corporis Fabrica Libri Septem. Ex Officina Joannis Oporini.

Wernicke, K., 1874. Der Aphasische Symptomenkomplex: Eine Psychologische Studie auf Anatomischer Basis. Cohn and Weigert.

Wickens, A., 2014. A History of the Brain: From Stone Age Surgery to Modern Neuroscience. Psychology Press.

Wright, C., Bechtel, W., 2007. Mechanisms and psychological explanation. In: Thagard, P. (Ed.), Handbook of Philosophy of Psychology and Cognitive Science. Elsevier, pp. 31-79.

Zeki, S., Watson, J., Lueck, C., Friston, K., Kennard, C., Frackowiak, R., 1991. A direct demonstration of functional specialization in human visual cortex. Journal of Neuroscience 11 (3), 641-649. 